\title{
Risk of developing diabetes mellitus in primary care health users: a cross-sectional study
}

\section{Lucas de Oliveira Araújo ${ }^{a}$ \\ Elaine Souza e Silvab Jediane de Oliveira Mariano ${ }^{\text {b }}$ \\ Ricardo Castanho Moreira ${ }^{a}$ Kelly Holanda Prezotto ${ }^{a}$ Carlos Alexandre Molena Fernandes ${ }^{c}$ Sonia Silva Marcon ${ }^{d}$}

D0l: $\quad$ http://dx.doi.org/10.1590/1983-

1447.2015.04.50195

\footnotetext{
a Universidade Estadual do Norte do Paraná (UENP), Setor de Enfermagem. Bandeirantes, Paraná, Brasil.

b Universidade Estadual do Norte do Paraná (UENP), Curso de Graduação em Enfermagem. Bandeirantes, Paraná, Brasil.

c Universidade Estadual do Paraná (UNESPAR). Paranavaí, Paraná, Brasil.

¿ Universidade Estadual de Maringá (UEM). Maringá, Paraná, Brasil.
}

\section{ABSTRACT}

Objective: to identify the risk of developing diabetes mellitus among primary care users in a municipality of the Southern Brazil. Method: data were collected from October 2013 to April 2014 by applying the Finnish Diabetes Risk Score questionnaire on 189 users. Results: the majority of the interviewees presented a slight moderate to moderate risk of developing diabetes mellitus (63.5\%). There was a greater prevalence of high risk among the men. The variables with a significant prevalence ratio for high risk were age, obesity, abdominal circumference, sedentarism and family history of diabetes mellitus.

Conclusion: the identified risk factors for diabetes reveal the importance of the health team and how it can intervene to prevent disease.

Keywords: Diabetes mellitus. Risk. Primary health care.

\section{RESUMO}

Objetivo: identificar o risco para o desenvolvimento do diabetes mellitus em usuários da atenção básica em um município do Sul do Brasil.

Método: os dados foram coletados no período de outubro de 2013 a abril de 2014 com aplicação do Finnish Diabetes Risk Score em 189 usuários.

Resultados: os resultados mostraram que a maioria dos entrevistados apresentou risco discretamente moderado e moderado (63,5\%). Houve maior prevalência de alto risco para 0 gênero masculino. Entre as variáveis que apresentaram razão de prevalência significativa para 0 alto risco, encontram-se a idade, obesidade, circunferência abdominal, sedentarismo e histórico familiar de diabetes mellitus.

Conclusão: a partir da identificação dos fatores de risco para o diabetes, destaca-se a importância da equipe de saúde na intervenção sobre os que podem ser modificados com o objetivo da prevenção da doença.

Palavras-chave: Diabetes mellitus. Risco. Atenção primária à saúde.

\section{RESUMEN}

Objetivo: identificar el riesgo de desarrollo de diabetes mellitus en los usuarios de la atención primaria en una ciudad del sur de Brasil. Método: los datos fueron recogidos a partir de octubre de 2013 a abril de 2014 sobre la aplicación de la Escala de Riesgo de Diabetes de Finlandia en 189 usuarios.

Resultados: Ios resultados mostraron que la mayoría de los encuestados tenía riesgo discretamente moderado y moderado (63.5\%). Hubo una mayor prevalencia de alto riesgo para los varones. Entre las variables que mostraron relación significativa prevalencia de alto riesgo son la edad, la obesidad, circunferencia de la cintura, la inactividad física y los antecedentes familiares de diabetes mellitus. Conclusión: en la identificación de los factores de riesgo para la diabetes, se destaca importancia de los profesionales de salud para intervenir en los que se puede modificar con el objetivo de la prevención de enfermedades.

Palabras clave: Diabetes mellitus. Riesgo. Atención primaria de salud. 


\section{DINTRODUCTION}

Type 2 Diabetes mellitus (DM2) is one of the most common chronic diseases in the world. An estimated 347 million people suffer from $\mathrm{DM} 2^{(1)}$.

DM2 can remain asymptomatic for a long period making a diagnosis based on symptoms difficult. Consequently, primary care teams must also pay attention to the risk factors ${ }^{(2)}$.

The risk factors for DM2 are a family history of diabetes, high blood pressure (>140/90 mmHg) or use of medication for hypertension among adults, history of gestational diabetes or infants that weigh more than $4 \mathrm{Kg}$, dyslipidemia (triglycerides $>250 \mathrm{mg} / \mathrm{dl}$ and $\mathrm{HDL}<35 \mathrm{mg} / \mathrm{dl}$ ), prior glycated haemoglobin test (HbA1c) $\geq 5.7 \%$, diminished tolerance to glucose, impaired fasting glucose, severe obesity, polycystic ovary syndrome, history of cardiovascular disease, physical inactivity, aged $\geq 45$ and moderate cardiovascular risk ${ }^{(3)}$.

In general, only people with a high risk for DM2 are referred to screening and undergo blood glucose tests ${ }^{(3)}$. This has led to the application of scales that allow the identification of subjects with undiagnosed DM2 or who are at risk of developing DM2 in the coming years( ${ }^{(4)}$.

One of these scales is the Finnish Diabetes Risk Score - FINDRISC, which is a low-cost, quick and non-invasive instrument that determines the risk for developing of DM2 in the next 10 years ${ }^{(5)}$.

Considering the importance of identifying risk for DM2 to modify this risk or delay the appearance of the disease, the aim of this paper is to identify the risk of developing DM2 among users of a primary care service in a municipality of southern Brazil.

\section{DETHOD}

This is a cross-sectional study conducted in primary care units (UBS) of a municipality in the southern region of Brazil. The municipality has six UBS with a family health strategy service and a central primary care unit with the community health agents programme. These units attend an estimated $64.79 \%$ of the local population.

The study sample consisted of UBS users without a DM2 diagnosis. The inclusion criteria were subjects over the age of 18 and subjects residing in the municipality of the study. The exclusion criteria were subjects with a prior DM2 diagnosis, subjects with impaired communication and pregnant women.

The sample was calculated according to a confidence level of $95 \%$, an accuracy of $6 \%$, an estimated replacement rate of $5 \%$ and a prevalence of expected outcome (Findrisc $>=15$ points) of $19.5 \%{ }^{(4)}$. Considering the population in each UBS, the sample comprised of 189 individuals proportionally divided between the seven health units.

The employed selection technique was non-probability sampling, where the individuals who attended the UBS of their own free will or for a routine appointment were invited by the researchers to participate in the study.

Data were collected by researchers who were receiving training on research instruments. The data collection period was October 2013 to April 2014. The study was conducted at each UBS consecutively, which resulted in an extended collection period. The interviews were conducted in an appropriate room at each health unit to ensure privacy and comfort for the participants of the study.

Data were collected using two instruments. The first instrument was a questionnaire consisting of socio-economic variables (sex and income) and anthropometric measurements (weight, height and waist circumference). The second instrument was a questionnaire based on the Finnish Diabetes Risk Score - FINDRISC, which was created in Finland and validated by the Department of Public Health of the University of Helsinki. The instrument has not been validated for Portuguese to date, however, it has been used in other Brazilian studies ${ }^{(6-7)}$, and it is used by the Centro de Referência Estadual para Assistência a Diabetes e Endocrinologia da Bahia(7), a state-owned reference centre for diabetes and endocrinology in the Brazilian state of Bahia.

The instrument consists of eight variables, namely age ( $<45$ years, 45-54 years, 55-64 years and $>64$ years), waist circumference $(<94 \mathrm{~cm}, 94-102 \mathrm{~cm}$ or $>102 \mathrm{~cm}$ for men and $<80 \mathrm{~cm}, 80-88 \mathrm{~cm}$ or $>88 \mathrm{~cm}$ for women), body mass index ( $<25,25-30$ or $>30$ ), physical activity (at least 30 minutes: yes or no), diet (regular intake of vegetables and/ or fruits: every day or sometimes), use of blood pressure medication (yes or no), family history of diabetes (no, yes: grandparents, uncles or cousins or yes: parents, siblings and children) and a history of high blood glucose (yes or no, at any time of the day).

Height and weight were recorded in a single session while the subjects remained immobile in a standing position with their hands flat on their thighs and their heads adjusted according to the Frankfurt plane. The Filizola ${ }^{\oplus}$ scale was used for these measurements, with a maximum of $2 \mathrm{~m}$ with a precision of 1 centimetre, and a capacity of $150 \mathrm{~kg}$ with a precision of $0.1 \mathrm{~kg}$.

The body mass index was calculated by dividing the weight in kilograms by the height in metres, squared. The waist circumference was measured using a centimetre tape measure between the iliac crest and the last rib and 
between inspiration and expiration of the participant. The other variables were stated by the participants.

Each FINDRISC variable consists of a score. The sum of the scores generates a final score that ranges from 0 to 24 . The scores are categorized according to the risk of developing DM2, namely low risk (<7 points), slightly moderate risk (between 7 and 11 points), moderate risk (between 12 and 14 points), high risk (between 15 and 20 points), and very high risk (more than 20 points). This scale has a sensitivity of $81 \%$ and a specificity of $76 \%$ in predicting DM2 treated with medication ${ }^{(8)}$.

The data were double-entered in an Microsoft ${ }^{\oplus}$ Excel spreadsheet and exported to the Statistical Package for Social Sciences - SPSS, version 18.0. Descriptive statistics was used to calculate the frequency, expressed in absolute number and percentage.

Subsequently, the FINDIRISC was recategorized as a dichotomous variable with the values of $<15$ points and $\geq 15$ points, as proposed by other author ${ }^{(4-5)}$, respectively representing low to moderate risk and high to very high risk. This recategorization was considered the main outcome of the study. Inferential statistics was used to compare the characteristics associated to this outcome by crossing the gross prevalence rates with the confidence interval of $95 \%$.

The study considered all ethical precepts of Resolution 466/2012 and was approved by the Comitê de Ética em Pesquisas [CAAE no 20238513.7.0000.0108]. All the participants signed an informed consent statement.

\section{RESULTS}

The sociodemographic characteristics of the 189 participants of the study are listed in Table 1. The data show that most of the participants were women (75.1\%) under the age of 45 (49.7\%).

Table 1 also shows the characteristics related to body mass, where $25.4 \%$ of the individuals had a BMl greater than 30 , most of the individuals did not practice physical activity (50.8\%) and 52.4\% did not consume fruit and vegetables on a daily basis. Of all the respondents, $30.7 \%$ used medication for hypertension and $11.6 \%$ reported a history of hyperglycaemia. In relation to a family history of DM2, $54.5 \%$ reported having parents, siblings, grandparents, uncles or first cousins who suffered from the disease.

In relation to risk, $18 \%$ of the respondents presented a low risk and $1.1 \%$ presented a very high risk of developing DM2. Most of the participants presented a slightly high risk (35.4\%) (Figure 1).

Table 2 shows the significant differences in the prevalence of risk factors: increased age, $\mathrm{BMI}>30$, increased
Table 1 - Distribution of users of primary care units according to sociodemographic and individual characteristics. Bandeirantes, Paraná, 2014

\section{Variables}

N (\%)

\section{Sex}

Male

$47(24.9)$

Female

$142(77.1)$

Age

$\begin{array}{ll}<45 \text { years } & 94(49.7) \\ 45 \text { to } 54 \text { years } & 39(20.6) \\ 55 \text { to } 64 \text { years } & 30(15.9) \\ >64 \text { years } & 26(13.8)\end{array}$

BMI

$<25$

25 to 30

$78(41.3)$

$>30$

$48(25.4)$

Abdominal circumference
$M<94 / F<80$
$45(23.8)$
M 94 to 102/F 80 to 88
$47(24.9)$
$M>102 / F>88$
$97(51.3)$

\section{Practice physical activity}

Yes

$93(49.2)$

No

$96(50.8)$

Intake of fruit and vegetables

$\begin{array}{ll}\text { Every day } & 90(47.6) \\ \text { Sometimes } & 99(52.4)\end{array}$

Medication for hypertension

No

$131(69.3)$

Yes

$58(30.7)$

\section{History of hyperglycaemia}

$\begin{array}{ll}\text { No } & 167(88.4) \\ \text { Yes } & 22(11.6)\end{array}$

\section{Family history of DM2}

$\begin{array}{ll}\text { No } & 86(45.5) \\ \text { Yes (grandparents, uncles and cousins) } & 33(17.5) \\ \text { Yes (parents and siblings) } & 70(37.0)\end{array}$

Source: Research data, 2014.

BMI (Body Mass Index); DM2 (diabetes mellitus type 2)

waist circumference, physical activity, infrequent intake of fruit and vegetables, medication for hypertension, personal history of hyperglycaemia and family history of DM2 (parents or siblings). 


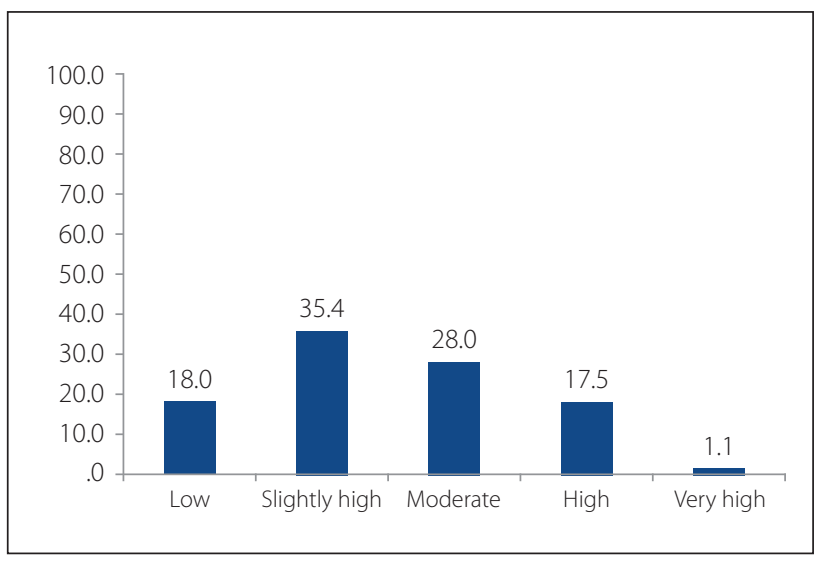

Figure 1 - Distribution of users of primary care units according to level of risk of developing DM2. Bandeirantes, Paraná, 2014

Source: Research data, 2014

A high risk of developing DM2 was more prevalent among the men - approximately 1208 times more prevalent than among the women. Significant results were found for all the comparisons in relation to age (Table 2).

In relation to the variable family history of $\mathrm{DM} 2$, subjects with a family member with DM2 represented a higher risk of developing DM2 (PR: 3.992; Cl 95\% 1.930 to 8.259).

\section{DISCUSSION}

The aim of this study was to identify the risk of developing DM2 among users of a primary care unit in a municipality of southern Brazil. The identification of risk factors is considered fundamental for the creation of actions that effectively impact the health/disease process and prevent the occurrence of diseases ${ }^{(4,9)}$.

The importance of the occurrence of DM2 lies in the morbidity and mortality associated with the disease. Recently published data indicates a significant increase in deaths caused by DM2 in 25 Brazilian capitals cities ${ }^{(10)}$. In addition to the mortality, the consequences of DM2 on human health, such as problems related to vision, the heart and the circulatory system, sleep and back problems ${ }^{(11)}$, negatively affect the quality of life of sufferers.

There was a higher prevalence of users with low risk and slightly moderate risk of DM2. However, this finding must be analyzed with caution since the random manner in which the participants were recruited can be considered a limitation of the study. Literature shows that users who seek health services tend to have greater control over their health and greater awareness of how to prevent chronic diseases ${ }^{(12)}$.
Among the participants of this research, $18.6 \%$ presented a high and very high risk of developing DM2 in the next 10 years. These results are slightly lower than results found in a study in Spain(4), where $19.5 \%$ of primary care users showed a high risk of developing the disease, and much higher than findings of a study in Portugal with users of health centres, where $12.8 \%$ presented a high and very high risk of developing $\mathrm{DM}^{(5)}$.

In north-eastern Brazil, a high risk of developing the disease was found in $11.7 \%$ of users of primary care units(6). Research that assesses the risk of DM2 in other populations of non-users of healthcare units also refer to the findings of this study. A study with bank employees showed that 3.8\% of the participants had a high risk of developing diabetes mellitus ${ }^{(7)}$. The low percentage is justified because it was conducted with a younger population that is still in the labour market.

Preventing key diseases in a population is one of the tasks of a primary care team. Several programmes have been implemented to prevent disease, especially chronic diseases ${ }^{(2)}$ and their complications.

The risk factors already described in literature have been confirmed in this research. The variables obesity, increased waist circumference, a sedentary lifestyle, restricted intake of fruit and vegetables and a family history of DM2 were associated to a high and very high risk of developing DM2. Consequently, strategies to prevent the occurrence of DM2 based on recognizing the risks are essential to ensure the promotion of health among the population.

Interestingly, most of the participants of this study were women, which reinforces the verified predominance of women in health units ${ }^{(13)}$. This finding can cause some concern because it reveals that most of the high risk users are men. Men tend to have a self-care deficit, which implies a higher rate of morbidity and mortality among this population ${ }^{(14)}$.

In relation to the general characteristics of the sample, a study that sought to identify the risks of developing DM2 in north-eastern Brazil showed that 59\% of the users were overweight, $84 \%$ had abdominal obesity and $83.3 \%$ were sedentary ${ }^{(6)}$.

Another study conducted in Europe corroborates the findings of the present study and reveals that $42 \%$ of the participants had an increased abdominal circumference, $45 \%$ did not practice any physical activity and $45 \%$ had at least one family member with diagnosed $\mathrm{DM}^{(5)}$.

A study conducted in Pelotas, in southern Brazil, showed that only $20.9 \%$ of the adult population regularly consuming fruits and vegetables, especially men, people 
Table 2 - Distribution of users according to characteristics of the FINDRISK questionnaire by classification of risk and prevalence ratio for high/very high risk of developing DM2. Bandeirantes, Paraná, 2014

\begin{tabular}{|c|c|c|c|c|}
\hline Variables & $\begin{array}{c}<15 \\
N(\%)\end{array}$ & $\begin{array}{l}>=15 \\
N(\%)\end{array}$ & PR & $\mathrm{Cl}(95 \%)$ \\
\hline \multicolumn{5}{|l|}{ Sex } \\
\hline Female & $117(82.4)$ & $25(17.6)$ & 1 & \\
\hline Male & $37(78.7)$ & $10(21.3)$ & 1.208 & $0.627-2.326$ \\
\hline \multicolumn{5}{|l|}{ Income } \\
\hline 0 to 1000 & $85(82.5)$ & $18(17.5)$ & 1 & \\
\hline 1001 to 1500 & $37(84.1)$ & $7(15.9)$ & 0.910 & $0.409-2.023$ \\
\hline 1501 to 2000 & $14(77.8)$ & $4(22.2)$ & 1.271 & $0.486-3.323$ \\
\hline Over 2000 & $18(75.0)$ & $6(25.0)$ & 1.430 & $0.636-3.216$ \\
\hline \multicolumn{5}{|l|}{ Age } \\
\hline$<45$ years & $91(96.8)$ & $3(3.2)$ & 1 & \\
\hline 45 to 54 years & $26(66.7)$ & $13(33.3)$ & 10.444 & $3.150-34.627$ \\
\hline 55 to 64 years & $24(80.0)$ & $6(20.0)$ & 6.266 & $1.668-23.542$ \\
\hline$>64$ years & $13(50.0)$ & $13(50.0)$ & 15.666 & $4.824-50.876$ \\
\hline \multicolumn{5}{|l|}{$\mathrm{BMI}$} \\
\hline$<25$ & $59(93.7)$ & $4(6.3)$ & 1 & \\
\hline 25 to 30 & $64(82.1)$ & $14(17.9)$ & 2.826 & $0.979-8.163$ \\
\hline$>30$ & $31(64.6)$ & $17(35.4)$ & 5.578 & $2.006-15.506$ \\
\hline \multicolumn{5}{|l|}{ Abdominal circumference } \\
\hline$M<94 / F<80$ & $44(97.8)$ & $1(2.2)$ & 1 & \\
\hline M 94 to 102/F 80 to 88 & $39(83.0)$ & $8(17.0)$ & 7.659 & $0.997-58.804$ \\
\hline$M>102 / F>88$ & $71(73.2)$ & $26(26.8)$ & 12.061 & $1.689-86.126$ \\
\hline \multicolumn{5}{|l|}{ Physical activity } \\
\hline Yes & $83(89.2)$ & $10(10.8)$ & 1 & \\
\hline No & $71(74.0)$ & $25(26.0)$ & 2.421 & $1.232-4.759$ \\
\hline \multicolumn{5}{|l|}{ Intake of fruit and vegetables } \\
\hline Every day & $83(92.2)$ & $7(7.8)$ & 1 & \\
\hline Sometimes & $71(71.7)$ & $28(28.3)$ & 3.636 & $1.671-7.912$ \\
\hline \multicolumn{5}{|l|}{ Medication for hypertension } \\
\hline No & $121(92.4)$ & $10(7.6)$ & 1 & \\
\hline Yes & $33(56.9)$ & $25(43.1)$ & 5.646 & $2.903-10.979$ \\
\hline \multicolumn{5}{|l|}{ History of hyperglycaemia } \\
\hline No & $140(83.8)$ & $27(16.2)$ & 1 & \\
\hline Yes & $14(63.6)$ & $8(36.4)$ & 2.249 & $1.172-4.316$ \\
\hline \multicolumn{5}{|l|}{ Family history of DM2 } \\
\hline No & $78(90.7)$ & $8(9.3)$ & 1 & \\
\hline Yes (parents, siblings or children) & $44(62.9)$ & $26(37.1)$ & 3.992 & $1.930-8.259$ \\
\hline Yes (grandparents, uncles or first cousins) & $32(97.0)$ & $1(3.0)$ & 0.325 & $0.042-2.504$ \\
\hline
\end{tabular}

Source: Research data, 2014

BMI (Body Mass Index); DM2 (diabetes mellitus type 2) 
of lower socio-economic level and those who did not practice regular physical activity ${ }^{(15)}$.

Physical activity, which is a protective factor against several diseases, is another important attribute of public health. The habit of exercise should be initiated at childhood and consolidated in adolescence for its maintenance in adulthood and among the elderly population, and primary care should encourage and monitor physical activity ${ }^{(2)}$. A study conducted in several regions of Brazil revealed the prevalence of insufficient physical activity ( $<150$ minutes week) among $66.6 \%$ of adults and $73.9 \%$ of the elderly ${ }^{(16)}$.

Literature shows that physical activity and dietary education is essential for the prevention of DM2 $2^{(17)}$. However, a study conducted in south-eastern Brazil revealed that information on healthy practices is insufficient in primary health care, and that the major barriers of physical activity are lack of time (27.5\%) and the need to change habits $(23 \%)^{(18)}$.

Another study highlighted that only $50.9 \%$ of a population that received guidance and follow-up on healthy practices adhered to these habits, and that the perception of having a healthy diet and of participating in a public healthcare promotion service were factors that positively influenced adherence to healthy habits. Contrarily, difficulties to change habits and lack of time were the most commonly reported barriers ${ }^{(12)}$.

Therefore, it is important to address the prevalence of risk factors among the population. Health care professionals, especially nurses who work in primary care, are responsible for promoting health and implementing protective actions for $\mathrm{DM} 2^{(12)}$.

Promoting physical activity and a healthy diet is therefore a challenge for the obtainment of an ideal BMI and for reducing the risk of developing DM2. A study conducted in Minas Gerais identified that the professionals who work with DM2 awareness practices in primary care do not sufficiently communicate with users and fail to identify the roles and relationships, which hinders the establishment of goals and self-care that DM2 requires ${ }^{(19)}$.

Consequently, nursing interventions are a priority to control DM2. Ideally, nurses participate in dietary education, reinforce the need of physical activity, promote adherence to medication and address health promotion issues of sufferers of $\mathrm{DM} 2^{(20)}$.

Health education based on creating awareness on healthy habits and risk factors for DM2 is an important prevention strategy, and these interventions must also be included in the family circle.

This study revealed the relationship between having a direct family member with (parents and siblings) with DM2 and the high risk of acquiring the disease. This relationship is mostly based on shared risk-related habits that can trigger DM2, such as diet. The protection and risk factors for developing DM2 are determined by the lifestyle of individuals, and the risks always entail negative consequences for their health (2). Acknowledging the individual risk in a family group where the members share the same habits is fundamental for the joint prevention of DM2.

\section{CONCLUSION}

The results of this study show that the risk factors for developing DM2 were present in the studied population. The application of the FINDRISC questionnaire helps to identify the key factors that can trigger DM2, such as obesity, increased waist circumference and a prior history of hyperglycaemia. The healthcare team must regularly check the glucose levels of users for the early identification of prediabetes and, above all, intensify interventions to change habits that hinder the appearance of DM2.

We recommend long-term studies to monitor highrisk individuals that participate in actions that encourage a change of habits to delay or prevent the disease. Research on the effective implementation of health diet policies, regular physical activity and knowledge on DM2 are also necessary, considering that the risk factors are widely known but the characteristics and habits of the population do not favour prevention of this disease.

\section{REFERENCES}

1. Danaei G, Finucane MM, Lu Y, et al. National, regional, and global trends in fasting plasma glucose and diabetes prevalence since 1980: systematic analysis of health examination surveys and epidemiological studies with 370 country-years and 2.7 million participants. Lancet. 2011;378(9785):31-40.

2. Ministério da Saúde (BR). Secretaria de Atenção à Saúde. Departamento de Atenção Básica. Estratégias para o cuidado da pessoa com doença crônica: diabetes mellitus. Brasília: Ministério da Saúde; 2013.

3. American Diabetes Association (US). Diagnosis and classification of diabetes mellitus. Diabetes Care. 2010;33(Suppl 1):S62-9.

4. Salinero-Fort MA, Pau ECS, Abánades-Herranz JC, Dujovne-Kohan I, Cárdenas-Valladolid J. Riesgo basal de diabetes mellitus em atención primaria según cuestionario FINDRISC, factores asociados y evolución clínica tras 18 meses de seguimiento. Rev Clin Esp. 2010;210(9):448-53.

5. Valente T, Azevedo L. Estudo Radar: risco aumentado de diabetes em Amarante. Rev Port Med Geral Fam. 2012;28(1):18-24.

6. Marinho NBP, Vasconcelos HCA, Alencar AMPG, Almeida PC, Damasceno MMC. Risco para diabetes mellitus tipo 2 e fatores associados. Acta Paul Enferm. 2013;26(6):569-74.

7. Bittencurt A, Vinholes DB. Estimativa do risco para diabetes mellitus tipo 2 em bancários da cidade de Tubarão, estado de Santa Catarina, Brasil. Sci Med. 2013;23(2):82-9. 
8. Lindströn J, Tuomilehto J. A pratical tool to predict tipe 2 diabetes risk. Diabetes Care. 2003;26(3):725-31.

9. Almeida VCF, Zanetti ML, Almeida PC, Damasceno MMC. Ocupação e fatores de risco para diabetes tipo 2: estudo com trabalhadores de enfermagem. Rev Lat-Am Enfermagem. 2011;19(3):476-84.

10. Mattos PE, Luz LL, Santiago LM, Mattos IE. Tendência da mortalidade por diabetes mellito em capitais brasileiras, 1980-2007. Arq Bras Endocrinol Metabol. 2012;56(1):39-46.

11. Santos EA, Tavares DMS, Rodrigues LR, Dias FA, Ferreira PCS. Morbidades e qualidade de vida de idosos com diabetes mellitus residentes nas zonas rural e urbana. Rev Esc Enferm USP. 2013;47(2):393-400.

12. Toledo MTT, Abreu MN, Lopes ACS. Adesão a modos saudáveis de vida mediante aconselhamento por profissionais de saúde. Rev Saude Publica. 2013;47(3):540-8.

13. Tomasi E, Facchini LA, Thumé E, Piccini RX, Osorio A, Silveira DS, et al. Características da utilização de serviços de atenção básica à saúde nas regiões sul e nordeste do Brasil: diferenças por modelo de atenção. Cienc Saude Colet. 2011;16(11):4395-404.

14. Fontes WD, Barboza TM, Leite MC, Fonseca RLS, Santos LCF, Nery TCL. Atenção à saúde do homem: interlocução entre ensino e serviço. Acta Paul Enferm. 2011;24(3):430-3.
15. Neutzling MB, Airton JR, Mario RA, Pedro-Hallal C. Fatores associados ao consumo de frutas e vegetais entre adultos de uma cidade do sul do Brasil. Cad Saúde Pública. 2009;25(11):2365-74.

16. Madeira MC, Siqueira FCV, Facchini LA, Silveira DS, Tomasi E, Thumé E, et al. Atividade física no deslocamento em adultos e idosos do Brasil: prevalências e fatores associados. Cad Saude Publica. 2013;29(1):165-74.

17. Bruno A, Pereira LR, Almeida HS. Avaliação da prevalência de fatores de risco para 0 desenvolvimento de diabetes mellitus tipo 2 em pacientes da clínica Unesc Saúde. Demetra. 2014;9(3):661-80.

18. Santos RP, Horta PM, Silva CS, Santos CA, Oliveira HBS, Almeida LMR, et al. Aconselhamento sobre alimentação e atividade física: prática e adesão de usuários da atenção primária. Rev Gaúcha Enferm. 2012;33(4):14-21.

19. David GF, Torres HC, Reis IA. Atitudes dos profissionais de saúde nas práticas educativas em diabetes mellitus na atenção primária. Cienc Cuid Saúde. 2012;11(4):758-66.

20. Scain SF, Franzen E, Santos, LB, Heldt, EPS. Acurácia das intervenções de enfermagem para pacientes com diabetes mellitus tipo 2 em consulta ambulatorial. Rev Gaúcha Enferm. 2013;34(2):14-20.0

\section{Author's address:}

Lucas de Oliveira Araújo

Rodovia BR-369, Km 54, Vila Maria, CP 261

86360-000 Bandeirantes - PR

E-mail: lucasaraujo@uenp.edu.br
Received: 12.09.2014

Approved: 31.08.2015 